\title{
Taking back control
}

\author{
Article
}

Accepted Version

Jubb, R. (2020) Taking back control. Critical Review of International Social and Political Philosophy. ISSN 1743-8772 doi: https://doi.org/10.1080/13698230.2020.1738067 Available at https://centaur.reading.ac.uk/89495/

It is advisable to refer to the publisher's version if you intend to cite from the work. See Guidance on citing.

Published version at: https://www.tandfonline.com/doi/full/10.1080/13698230.2020.1738067

To link to this article DOI: http://dx.doi.org/10.1080/13698230.2020.1738067

Publisher: Routledge

All outputs in CentAUR are protected by Intellectual Property Rights law, including copyright law. Copyright and IPR is retained by the creators or other copyright holders. Terms and conditions for use of this material are defined in the End User Agreement.

\section{www.reading.ac.uk/centaur}

\section{CentAUR}

Central Archive at the University of Reading

Reading's research outputs online 


\section{Taking Back Control}

\section{Introduction}

One way in which the theorizing of analytical political theorists and philosophers has changed in the last decade or so is by understanding the international realm in more sophisticated ways. Analytical political theory and philosophy had, until relatively recently, mainly considered questions of what members of different states might owe each other beyond the minimums of non-violence and humanitarian assistance in terms of a moral cosmopolitanism which makes us all primarily citizens of the world rather than of distinct polities (Ronzoni 2018). However, building on previous work stressing the interdependence between different states and their citizenries (Beitz 1975), analytical political theorists and philosophers have recently begun to conceptualize the international realm somewhat differently. Work has increasingly stressed the extent to which states are subjected to powerful international forces which seem to require forms of regulation beyond those possible with bilateral agreements. In order to protect their capacity to deliver the typically liberal-egalitarian goods to their citizens, states should form international organizations and institutions to shield themselves from the power of transnational commerce and capital, which may otherwise drive them into damaging races to the bottom (Ronzoni 2009).

This increasing awareness of the way in which international politics, in the broadest sense, structures the options realistically open to states has been accompanied by an increasing awareness of rising inequality over the past thirty or so years, at least in North Atlantic liberal democracies. ${ }^{i}$ Understanding the move away from a Rawlsian model of society "as a closed system isolated from other societies" as partly prompted by that growing inequality seems sensible (Rawls 1971, 8). Analytical political theorists and philosophers are overwhelmingly liberal-egalitarian in much the way Rawls' theory was (Bourget and Chalmers 2014, 483-484), and so must be disappointed by the now widespread understanding that inequality has been rising for three decades in the societies they mainly inhabit. That disappointment is likely to spread to their own political theorising insofar as its common sense, of a society as a closed system, serves as a barrier to conceptualizing and so countering at least some of the sources of their own societies' movement away from the ideals they espouse. Some partisans of the shift away from the contrast between bounded and global citizenship have even argued that analytical political theorists need to fundamentally reconsider how they understand the state, the powers it has and the threats to which it is subject (Ronzoni 2018). Yet there is a question about whether they have quite gone far enough.

Consider for example the story about the emptying out of the public sphere across the EU told by Peter Mair in his Ruling the Void (2013). On Mair's account, elites in the democratic states of 
Europe passed various aspects of policy up to the EU's supranational institutions and, by taking those issues off the domestic political agenda, contributed to declines in their accountability and representativeness that encouraged the public to increasingly withdraw from political life. That made political life in those states increasingly unstable, by contributing to reductions in both the level and extent of members of the public's political loyalties. That instability made political elites vulnerable, both as individual office-holders and as collective agenda-setters and decisionmakers, and so they further internationalised aspects of policy to create institutions beyond popular control which they could staff and use to decide issues on which their domestic publics could no longer be trusted to be sensible. That only further hollowed out the domestic political sphere, making it more unstable and so encouraging yet more internationalisation of policy. Mair's account of falling rates of participation, resulting instability and increasing internationalisation of policy does not just involve international institutions or forces affecting domestic politics. The motives of domestic politicians are crucial in explaining the expanding authority of the EU, which for them offers an arena in which they can increasingly secure their policy preferences. Causal influence operates in both directions; the domestic and the international are mutually interpenetrated. Seeing domestic politics as vulnerable to the unaccountable powers of the under-regulated international realm and devising schemes to control them is not, if Mair is right, an adequate account of the interactions between domestic and international politics. Mair's work suggests that it is a mistake for internationalising egalitarians to understand the interactions of domestic and international politics in terms of a series of threats to the domestic sphere which should be contained through international institutions of one sort or another. Analytical political theorists concerned to move beyond the dichotomy of bounded or global citizenship also need to consider both how any international institutions they advocate or propose will affect domestic politics and how those effects will themselves affect the international institutions which initially created them. How, for example, will processes of domestic political accountability, like those Mair argued were both being systematically undermined by and encouraging further European integration, both be affected by and themselves affect international institutions? The models of international and domestic political institutions with which internationalising egalitarians work must be dynamic, not static.

My aim in this paper is not just to substantiate the claim that contemporary internationalising egalitarians have not fully grasped the range of threats posed by the interactions of the domestic and international realms. I also hope to bring their work into dialogue with other parts of the historical tradition in which they sometimes identify themselves as working. Theorists advocating internationalising control of transnational flows of goods, capital and expertise have 
on occasion used the language of republicanism, as described by Philip Pettit and Quentin Skinner (Pettit 1997, Skinner 1997), to articulate their demands. Cécile Laborde and Miriam Ronzoni have taken what Skinner has fairly described as one of the two slogans of early modern republicanism, that it is only possible to be free in a free state (Skinner 2010), as the basis of their internationalising egalitarianism. On their account, states and so their citizens can only be free in an international order which uses counter-power, redistribution, democratisation, constitutionalisation and regulation to protect them against various sources of domination (Laborde and Ronzoni 2016). Yet their view does not really engage with the ways in which early modern republicans thought about the international order and the threats its existence meant free states had to face.

The risks which early modern republicans saw the international order as posing for states are not straightforwardly those which concern their contemporary counterparts when they consider what it is for a state to be free and so able to secure its citizens their proper status. The question of an armed citizenry is not central to neo-republicanism in contemporary analytical political theory and philosophy as it was for the tradition that began with Machiavelli (Pocock 1975), and with good reason. Even if contemporary North Atlantic states were as belligerent towards each other as their early modern counterparts were, volunteer militias would hardly be a central part of their war-making capacities. There are though resources to be drawn from the tradition J. G. A. Pocock helped bring to light which can help frame the efforts of contemporary egalitarians to use international institutions control increasing domestic inequality, resources which go beyond slogans about the relation of free states to free citizens or how to conceptualize, in the abstract, such freedom. The problematic that István Hont, following David Hume, called jealousy of trade can be helpfully deployed to understand the possibilities for limiting inequality in commercial societies like those in which the majority of contemporary analytical political theorists and philosophers live, as Hont himself insisted (Hont 2005). Its understanding of the way that domestic and international politics reflect back on each other usefully illustrates some of the difficulties contemporary internationalising egalitarians face. The rest of the paper will proceed as follows. I will begin by discussing the set of views I have already called internationalising egalitarianism, focusing in particular on Ronzoni's helpful conceptualization of the various different ways in which both philosophical and practical commitments can move beyond the contrast between closed societies and a cosmopolis. I will there draw on the problems Mair and Wolfgang Streeck have suggested the EU faces to serve as examples of the difficulties views like Ronzoni's have to overcome to usefully orient us towards the threats posed by the interactions between domestic and international politics. I will then move on to discuss jealousy of trade and how Hont used it to understand debates between 
members of what is often understood as the republican tradition, especially in the eighteenth century. As I hope to show there, jealousy of trade revolves around the way that international economic competition intensifies international political competition, requiring the restructuring of domestic politics to ensure the survival of the state, which then further intensifies international economic competition. The ways of navigating and controlling the increasing costs of an increasingly belligerent international order eighteenth century political theorists found help illustrate the challenges contemporary internationalising egalitarians face. I draw here particularly on Isaac Nakhimovsky's work on Johann Gottlieb Fichte's closed commercial state, which I argue is specially useful given the similarity of some of Fichte's commitments to those of contemporary internationalising egalitarians. I then conclude.

\section{Internationalising Egalitarianism}

The structuring of debates about international obligations in analytical political theory and philosophy, at least beyond those of a moral minimum, around a division between statists and cosmopolitans is, as theorists like Laborde and Ronzoni suggest, stale (James 2013). It does not adequately capture the range of different ways in which different agents can relate to each other across the globe, or the different structures through which those relations can be mediated. Iris Marion Young's social connection model is undoubtedly useful to grasp the problems of wrongs inflicted by unstructured collectives, but the idea that it can helpfully capture and articulate all the very different sets of considerations in play in her case of Sandy, the homeless single parent, in campaigns against the use of sweatshops by specific employers or institutions and in issues like global climate change is implausible (Young 2011). Likewise, Thomas Nagel's insistence that political institutions like those of contemporary liberal democracies generate special obligations amongst their members by engaging their will as both joint authors and joint subjects of the law seems right, but the extension of this claim by refusing to allow that there are any other relations which do anything similar is considerably less attractive (Nagel 2005). In that sense, moving beyond a division between cosmopolitans and statists is at least a step in the right direction for understanding how states and their citizens ought to act towards other states and their citizens, beyond respecting their sovereignty and basic human rights (Bellamy 2019).

Relying on the categorization of positions in debates within analytical political theory and philosophy over international obligations beyond a moral minimum as either cosmopolitan or statist has then obscured the range of different questions at stake there. Even calling those debates, as they typically are (Ronzoni 2018), debates about global justice unhelpfully replicates that binary division, by assuming there is a single normative object under question, justice, and the question being put is whether it applies across the globe or not. The set of questions at stake 
in analytical political theory's discussions of international obligations need to be complicated by allowing for a greater range of positions, and this is part of what figures like Laborde and Ronzoni hope to do. As well as her work with Laborde, the focus of which on how the international order might protect states and so their members against domination by various inter- and transnational actors and forces does not fit happily in the cosmopolitanism-statism frame, Ronzoni has also attempted to provide a more sophisticated typology for categorizing positions on international obligations beyond a moral minimum.

Ronzoni's typology suggests thinking of cosmopolitanism and statism as ends of a spectrum, and as applying across three connected but independent dimensions of morality, political action and institutions (Ronzoni 2018). A position on any of these dimensions is cosmopolitan insofar as its scope is properly global. Moral cosmopolitanism, for example, understands all humans as being members of the same community, owing each other the same substantive duties of justice in virtue of our shared humanity, while institutional cosmopolitanism demands a single global sovereign like a world state and political cosmopolitanism that the scope and audience of political action be global, in the way that some forms of Marxism have (Ronzoni 2018, 93-4). In contrast, moral, institutional and political statism restrict the sphere of operation of their respective concerns to the state. Once these different dimensions of views about international obligations beyond a minimum are distinguished, it becomes clear that can they come apart. Ronzoni suggests they do for example both in Kant's case, given the basis of his view in an equally held right to freedom but his suspicion about a world state, and in that of antiglobalisation activists', whose commitment to global action is not always matched by one to global institutions (Ronzoni 2018, 95). Relatedly, it also becomes clear that dichotomising the choice along any one of the dimensions is unhelpful. Ronzoni distinguishes three broad categories between cosmopolitanism and statism, supranationalism, transnationalism and internationalism. Supranantionalism identifies institutions, over and above states, which generate potentially quite thick normative demands; transnationalism instead focuses on shifting relationships and spheres of action which interpenetrate states and other institutions and their requirements; while internationalism concentrates on relations between states and how they must be made to work (Ronzoni 2018, 95ff).

Ronzoni's typology helpfully allows us to distinguish between different types of view. In particular, it allows her to demarcate and present a sketch of an argument for the kind of view she presented in her paper with Laborde. That view is morally internationalist, in that the agents for whom it demands respect and protection are states in their capacity to achieve equality domestically, but it is institutionally supranational, in that it requires authoritative international bodies which bind states into thick forms of regulations, and politically 
transnational, in that it is likely only to be brought about with the support of cross-national coalitions operating on shifting bases of interest and identity (Ronzoni 2018, 104ff). In that sense, Ronzoni's typology makes clear the kind of view which seems to be, at least for the time being, the most promising response from analytical political theorists and philosophers to our rediscovery of inequality and its presumed sources. The scope of egalitarian respect does not change significantly, in that it is primarily individual societies which should seek to control inequality between their members, but the mechanisms by which this is achieved are internationalised, both in terms of the agents that demand that control and the institutions that achieve it. This seems to recognise the proper source of demands for equality, in the possibilities for domination, exploitation and marginalization created by class and status hierarchies within the dense network of interconnections which make up a contemporary society (Jubb 2015). It also sees more clearly than the obvious available alternatives how those demands might best be answered. The clearest other way of considering how to reconceptualize the demands of equality and so the threats to it currently available is property-owning democracy, most closely associated with Martin O'Neill and Thad Williamson (O'Neill and Williamson 2012). However, this view adopts Rawls' institutional vision after which it is named wholesale, including its complete disinterest in interactions between domestic and international politics. This may have been appropriate when Rawls devised it in the world's largest economy under a regime of strict controls on international financial flows, but for those in any other situation, it looks dangerously naïve.

Ronzoni's typology does not just make it possible to clearly articulate and so demonstrate the attractions of the kind of view she favours. It also makes clear some of the difficulties it faces and tensions from which it suffers. The difficulties and tensions this paper hopes to expose can be helpfully framed in Ronzoni's typology. One of the central features of a domestic egalitarianism is a commitment to something like the forms of representative democracy, forms which cannot be obviously replicated or replaced by similar forms at a supranational level. Indeed, Laborde and Ronzoni see it as a strength of their view that it does not attempt to do so: the point of the supranational institutions for them is to prevent "the erosion of sovereign control of citizens over their domestic institutions" (Laborde and Ronzoni 2016, 283). Even if the regulation of states by supranantional institutions does at aggregate level protect domestic democratic authority, that will not mean that there has been no loss. Some democratic authority will have had to have been renounced and transferred to supranational institutions which will not only be answerable to any particular public which has passed it that authority, if to any at all. More, this may have the effect Mair and others like Wolfgang Streeck (2014) often claim those renouncing that authority intended, of creating technocratic elites unresponsive to the claims of the comparatively poorly off and so institutions which are not particularly good at the 
function internationalising egalitarians want them to perform, of empowering states to achieve domestic equality. Supranational institutions may be both intrinsically and instrumentally antiegalitarian, at least when one's egalitarianism is primarily domestic in the way that an internationalist like Ronzoni's is.

The tension may not just be between the institutional and egalitarian prescriptions. The transnational political struggles necessary to apply pressure for and to these supranational institutions may threaten forms of domestic political commitment. Even where these build on local forms of organisation and so are not atomising, they may require giving up or compromising existing domestic alliances and appeals and so undermining, for example, the party allegiances crucial to the proper functioning of representative democracy. Insofar as those allegiances typically operate to the benefit of the relatively disadvantaged by helping them to pool their political power in struggles with those with far greater political opportunities and resources, this is again not only an intrinsic threat to the domestic commitments of internationalist egalitarians, but also an instrumental one. And of course, the threat also runs the other way. Attempts to ensure that the operations of supranational institutions are in line with domestic political arrangements can conflict, resulting in power struggles which make those institutions into tools of some of their members rather than others, as Streeck argues has happened in the case of the Eurozone (Streeck 2017). As well as imperilling the function of such institutions to allow states to achieve rough socio-economic equality between their members, this is likely to make achieving transnational coalitions to reform them more difficult.

Ronzoni is aware of these problems, even if some of those more enthusiastic about the possibilities for internationalising egalitarianism seem blithely oblivious to the potential for widespread alienation and exclusion that transnational political movements and representation necessarily have in virtue of their transnational character (Wolkenstein 2018). She has discussed the ways in which three republican desiderata cut against each other, in particular once significant forms of binding regulation and governance become genuinely international (2017). On the one hand, being concerned to avoid domination means avoiding concentrations of power, while on the other it requires some such concentrations of formal legal power to bring informal social power under control. At the same time, any concentrations of power must be subject to strong forms of political accountability, which demands a vigorous culture of political participation. Such a culture of political participation can easily become moralizing in any number of ways and itself become a form of domination. Balancing these three concerns is difficult enough at the domestic level, as controversies over judicial review demonstrate. In the international realm, matters are complicated by the multiplication of different levels at which power can be exercised and contested. This creates the difficulty of ensuring that contestatory 
and regulatory energies do not dissipate ineffectively across these many sites of potential control without falling into the opposite trap of creating an unchallengeable global Leviathan. In the end, Ronzoni suggests that her work with Laborde points in the direction of the best balancing of the three republican desiderata. The model they develop there incrementally starts "from states", asking "what can be done to protect them from transnational forms of asymmetric power" while limiting the authority of international institutions, both for its own sake to guard against concentrated power and to ensure that "a sufficient level of civic engagement can be sustained" (Ronzoni 2017, 208). However, as we have already seen this does not capture the full range of risks which internationalising egalitarianism creates. The problem here is not an abstract one. Like other internationalising egalitarians (Bellamy 2019), Ronzoni has written on the EU (2017), presumably seeing in it at least the possibility of achieving the kind of control of transnational economic flows for which internationalising egalitarians in general hope. The worries Mair and Streeck and others like them have about the EU are based on real features of its politics. Those democratic deficits and dissatisfactions do not seem likely to disappear if the EU tries to orient itself around a more social democratic vision, not least because that would be widely resented in many of its member states which would then behave differently in the EU as it evolved over time. The dynamism of political institutions, whether domestic or international, and of their relations with each other, has to be a crucial part of any attempt to internationalise egalitarianism.

Seeing the importance of this dynamism is crucial. Mair's account of the underlying rationale for and dynamics of further EU integration may be wrong for all that it seems to be able to make sense of events since its production. Similarly, Streeck may not correctly characterize the situation when he attacks the EU as the enabler of the current instalment in a series of increasingly unstable political compromises designed to allow capital to escape sharing its surplus with labour (Streeck 2014). As Streeck emphasizes when discussing his own analysis (Streeck 2017), however, both these diagnoses of our present difficulties see them as part of an ongoing historical process whose various actors affect each other, often in ways they do not foresee or understand. This feature of their analyses seems crucial for whatever power they have. Consider, likewise, the end of the historically anomalous Trente Glorieuses which provided the background to Rawls' social democratic hopes. The Bretton Woods system collapsed under the pressure of the role the international order gave the United States, its effective guarantor. That process had a history, and if a return to some kind of Bretton Woods system is as central to (re)taming capitalism as figures like Streeck suggest (2014, 186ff), then understanding that it will develop, like all political arrangements, including not just the original Bretton Woods but also the other institutions with which it coexists and must coordinate, is crucial. States exist in 
an international order, whose political economy, mediated through their institutions, affects those same institutions, which, in turn, can themselves affect the international order. Managing that interaction must mean managing it over time, as the two sets of institutions change in response to each other. Expecting that reforming the international order can fix the problem of increasing inequality without considering how domestic political institutions will be affected by those changes cannot be adequate.

\section{Jealousy of Trade}

Hont's excavation of the problematic he, following Hume, called jealousy of trade can serve to illuminate the dynamics of the interactions between the various institutions and policies to which internationalising egalitarians look. He even only partly ironically suggested that one attempt to resolve the tensions of jealousy of trade, the Abbé de Saint-Pierre's Project for Settling an Everlasting Peace in Europe, is in effect a blueprint for the EU (Hont 2005, 27). Although Hont did not develop this thought in detail and certainly not in the context of internationalising egalitarianism, he was in general strongly committed to the idea that understanding the historically-derived assumptions which shape contemporary political thought can only be to its benefit, claiming that his work was produced "with eyes firmly fixed on the challenges of today". The eighteenth century is apparently particularly important in this respect, since, as he is often quoted claiming, "the commercial future many eighteenth-century observers imagined as plausible has become our historical present" (Hont 2005, 5, 156). This may overstate the case, and Hont was not always a very sympathetic observer of contemporary political thought, dismissing it as having failed to see the fundamental shift in both politics and, consequently, accurate thinking about it required by the development of commercial societies the eighteenth century foresaw (Hont 2015, 107, Sagar 2018, 12ff).

Nevertheless, Hont's own impatience should not prevent us from drawing on his work. By exploring the eighteenth century's commercial future and how it may have become our historical present in and through his work, we may be able to better understand the tensions our commitments may, in practice, both generate and help disguise. Straightforward cosmopolitans, for instance, seem to have to confront the enormous benefits for hundreds of millions of poor people that have followed and appear to have been caused by China and India's conversion, through entry into global markets, into increasingly commercial societies. The cost of those transformations has been enormous, both in China and India and elsewhere, and they are clearly not yet over. They are though presumably the single greatest reductions in human misery ever. At some point, even analytical political theorists whose egalitarianism is primarily domestically-oriented may need to consider the effects China's growth in particular will have on 
the international trading system, given how that is already affecting the North Atlantic societies about which they are most concerned. However, doing that will require absorbing lessons about the dynamism of the interpenetration of domestic and international politics jealousy of trade provides. The problematic of jealousy of trade is centrally concerned with the difficulties societies face in managing their exposure to international markets and the political conflicts, both domestic and international, that condition generates. That is, at root, the concern which motivates the group of contemporary analytical political theorists and philosophers hoping to internationalise control of domestic inequality. One fruitful way we can test Hont's claim to contemporary relevance is then by looking at their work, whose significance depends on acknowledging at least some of the issues Hont hoped to raise.

Jealousy of trade as described by Hont was structured around two competing logics, that of jealousy, in a now archaic sense of mutual suspicion and bellicosity, and of trade, which depends on the possibility of mutual benefit. These were brought together by the development of an international economy which enabled and encouraged the growth of large centralized states whose military prowess no longer depended on the martial virtues of their members, whether they be citizens generally or aristocrats and their clients and subjects in particular. Instead, the ability of these states to survive in an unruly international order rested on their power to extract, either through taxation or in loans, the resources to pay soldiers from their growing economies. This connection between prosperity and position vis a vis other states itself could generate conflict, since to pre-empt the development of relative weakness, states would seek to ensure access, ideally on preferential terms, to various economic opportunities. In seeking to create or protect monopolies, they would be driven to fight. The question posed by jealousy of trade was how this logic of a cycle of competition over resources to survive that same competition could be broken. Unless it could be broken, the increasing military power of these increasingly bellicose states would be unleashed against each other increasingly often, with increasingly bloody and destructive results.

Various schemes, at varying levels of detail, for dealing with the deeper and deeper links between a society's prosperity and its position in the international system were developed by eighteenth century theorists and philosophers. The crucial issue was to harmonize the motives and opportunities created by a society's economic system and those required for sustaining international peace. This could be done by eliminating the need for military competition through a federation of states, as Saint-Pierre proposed, or by restructuring economies so that they ceased to encourage hostile engagement with neighbours. Perhaps an enforced return to a predominantly agricultural existence would break the mutually reinforcing relation between economic growth and military conflict, as Fénelon argued in Telemachus. Another alternative 
was the hope that the logic of trade could liberate itself from its connection with war, either by equalizing the forces that different European states could bring to bear on each other in any conflict or by binding them together tightly enough to make conflict unattractive, if not both simultaneously.

Hont's problematic is centrally concerned with the political effects of increasing economic interdependence and interpenetration, and, most important for our purposes here, the inescapability of such effects. Open economies may well generate economic growth which benefits of the majority of their members, in the sense that they have access to a wider range of goods at lower cost. In the perhaps unlikely limit case, the majority who benefit in this sense from the increasing spread of commercial interactions and attitudes may include more or less all of a society's members. However, a society's members do not only assess its policies and institutions on the basis of whether they have received a narrowly economic benefit from them. Other considerations and other metrics also matter. The size and distribution of gains both within the polity and outside it, as well as, relatedly, questions of status and standing, all motivate citizens to support or object to and resist their political order. Political contention within a society is shaped by its penetration by international economic forces because different groups will have their differently conceived interests differently affected by those forces. Governments cannot but respond to that contention, but to do so, given the nature of the processes they must address, must involve them in the affairs of other states, which are similarly concerned to protect and promote the interests of at least some of their citizens. Which citizens exactly governments concern themselves with and in which ways inevitably varies from place to place and in different times. What does not change is that the claims their own citizens make overlap with those made by the citizens of other states. Conflicts emerge and for states empowered by the wealth provided by international trade, and particularly their expanded capacity to borrow to fund wars, international politics becomes a dangerous, sometimes zeroand even negative-sum game.

Hont's work, with others (Hont and Ignatieff 1983), to reconstruct of a problematic in which the political effects of international economic interdependence and interpenetration were inescapable helps us see and respond to a corresponding absence in internationalising egalitarianism. In general, internationalising egalitarians have not thought seriously about the full range of political effects which international cooperation to limit inequality might generate. Even setting aside those who benefit directly from rising inequality, who are of course political actors of very real power, those who are at least not made worse off in narrow economic terms by controlling inequality may nonetheless object to policies and institutions which do so. They may not connect whatever narrow economic benefits they receive with the policies and 
institutions responsible for producing them, expect to receive a greater share of the benefits of cooperation than they do, and resent the loss of status, community or any number of other not narrowly economic goods that internationally limiting inequality seems to them to require. Whether there are stable and acceptable institutions which can remove, alleviate or contain these costs and the political responses they will generate must be a central question for internationalising egalitarians, just as it was for theorists and philosophers working in the frame of jealousy of trade in the eighteenth century.

The various attempted resolutions of jealousy of trade interacted with related debates about the motivational bases of human sociability. If societies could only be stably formed on the basis of usually egalitarian virtue of one kind or another, then the prospects for reducing if not eliminating the logic of increasing international conflict through increasing international trade looked poor. Equality and virtue were threatened by the profit-seeking motives which had to dominate in a society dominated by commerce. Only if these motives could be made into the basis of a stable social order could they succeed in taming jealousy of trade, at least without unleashing the equally disastrous destruction of social order through domestic conflict. It is in this context, for example, that we should understand Adam Smith's famous remarks about not expecting our dinner from the benevolence but rather the self-interest of the baker and butcher (Smith 1975, 27). Similarly, the connection between the motivational basis of human sociability and jealousy of trade is central to understanding Rousseau's marked preference for organizing a society's economy on the basis of agriculture rather than commerce $(1997,75 \mathrm{ff})$. Conflicts over status would be almost impossible to contain unless the inequality commerce generated was contained, and in the end, a society dominated by commercial motives would be drawn into the spiral of corruption and violence detailed at the end of The Discourse on Inequality (1997, 185ff).ii

It is this connection between a society's international stance and its internal organizing principles which is central to jealousy of trade and most useful for thinking about internationalising egalitarianism. Some of the specific details of the connection described by jealousy of trade seem to have lapsed, perhaps because one or other of the methods proposed in the eighteenth century for controlling it have succeeded. It is more than seventy years since there was a major interstate war in Europe, and at least from the perspective of jealousy of trade it is difficult to see how that could have happened without at least Western European powers giving up their ambitions for global great power status and instead increasingly confederating in the EU. Insofar as Europe has been an arena of great power confrontation since the end of the Second World War, that conflict has been between predominantly extraEuropean powers who possessed military capabilities so unimaginably destructive they were 
extremely reluctant to take the enormous existential risk, even for the victors, using it against each other posed. Operating under the security umbrellas provided by those extra-European powers seems to form a crucial part of the background to the current historically unprecedented period of peace in Europe. The problem of military security has been removed as one of the drivers of a contemporary jealousy of trade, at least between European states. Their domestic arrangements are not now constrained by or oriented around the need to remain a sufficient military threat to their neighbours to deter aggression.

European states have not though by any means managed to eliminate all the interactions between their status relative to each other and their domestic social and political arrangements. Even without the threat of conquest or subjugation, their governments still face considerable pressure to ensure they are economically successful, at least for a sufficient proportion of the population for them to be re-elected. That pressure requires them to compete internationally to provide a hospitable and productive environment for capital and the inward and outward flows of goods and services from which it can extract returns. Internationalising egalitarians recognize and indeed rely on the existence of these pressure to open domestic economies to the forces of the international economic order. Those forces and their inegalitarian effects are precisely what internationalising egalitarianism hopes to control. The rationale for the position depends on them. As it stands though, the thought seems to be that once these forms of control have been implemented, the social democratic arrangements of (an increasingly less) slightly imaginary Sweden again become possible, as if once the international order and its institutions cease to force states towards inegalitarian accommodations with global capital, they cease to have any effects worth interrogating at all.

Jealousy of trade helps us interrogate the potential effects of the international order and its institutions by framing the problem as, in part, one of the basis on which we can reasonably expect a society to be organized. As we have seen, one of the basic divisions in debates around jealousy of trade in the eighteenth century was over the extent to which societies could be based on typically commercial motives and what the costs of doing so would be, given the domestic and international institutions in and with which their members would have to interact. There is a counterpart question for internationalising egalitarians. They tend to favour conceptualizing their commitment to equality as a relational one which aims at, as Elizabeth Anderson put it, "end[ing] oppression" and "creat[ing] a community in which people stand in relations of equality to others" $(1999,313,288-9)$. This relational egalitarianism straightforwardly requires that members of a society constitute those relations of equality through particular kinds of respect and regard for each other, including in their individual interactions with each other. If members of the society must accept "the obligation to justify their action by principles 
acceptable" to others and "take mutual consideration, reciprocation and recognition for granted" (Anderson 1999, 313), then members of the society will typically have to have characteristically egalitarian motives. Otherwise, the society will not be egalitarian in the relevant sense. As well as presenting an abstractly attractive picture of social relations then, insofar as internationalising egalitarian's proposals are supposed to answer the real problem of realizing egalitarianism in the world we know, they need to show those relations can sustain themselves as a coherent whole. This does not only involve showing that, understood as a closed domestic system in Rawls' sense they are stable, but also that they can sustain interactions with external forces, actors and institutions with whose existence they will have to cope and which are widely understood to threaten them.

As relational egalitarians sometimes themselves highlight (O'Neill 2008, 129), the egalitarian relations to which they are committed often seem rather Rousseauian, at least under a certain kind of reading of Rousseau (Neuhouser 2013). The wrongs of status hierarchies and the domination, exploitation, marginalization and humiliation they encourage if not directly create are at the centre of their view (Jubb 2015). Rousseau's work, though, needs to be seen in the frame of jealousy of trade, which gives it more of a unity than is perhaps often supposed. Neither Rousseau's insistence that Corsica's isolation and agricultural poverty made it the only society in Europe capable of living in freedom nor his insistence on non-denominational religiosity on penalties of exile for non-conversion and death for apostasy in The Social Contract are accidental $(1997,78,150)$. They are part of his response to the destructive power he attributed to commerce and luxury and the necessity of social unity to resist it and other forms of corruption, which would otherwise create relations of domination and dependence. The relations of equality which, at least in the abstract, both Rousseau and contemporary relational egalitarians demand are, for Rousseau, only realisable in tightly knit, puritanical, censorious and poor communities. iii This is not an attractive picture of how to sustain a community in which people stand in relations of equality to each other.

We now know that Rousseau's methods are certainly not always and perhaps even typically necessary. Slightly imaginary Sweden was once only slightly imaginary, just as the social democratic hopes of the democratic left in other North Atlantic societies in the Trente Glorieuses were once real and seemingly achievable aspirations. Even those societies though were typically more tightly knit, puritanical, censorious and poor than ours are now though. Bernard Williams was quite right to point out how unpalatable the environment which produced much of the support for the British Labour Party in its years of success after World War Two was in his polemics with G. A. Cohen over its late twentieth century turn away from the explicitly socialist commitments which had then animated it $(1997,55)$. Still, even Sweden in its social democratic 
heyday was not executing apostates. It would nonetheless be a mistake to dismiss Rousseau's concerns about the sustainability of roughly egalitarian social relations as totalitarian or prelapsarian fantasies because of what we now know about the success of less severe and illiberal mechanisms for generating community and solidarity. What we know is that those mechanisms can succeed for a certain period of time in a certain kind of international environment. We are neither sure that we can recreate that environment or another which provides similar protection nor that any such reforms and the patterns of increasingly equitable domestic prosperity we hope they will enable can last. There were, after all, only thirty of the Trente Glorieuse. The seemingly punitive demands for the suppression of difference associated with Rousseau's egalitarianism may be more realistic than we would like in a less hospitable international order than that supposed by slightly imaginary Sweden.

\section{The Closed Commercial State}

Isaac Nakhimovsky's work reconstructing Johann Gottlieb Fichte's account of what Fichte called the closed commercial state offers an alternative model of how to achieve control over international commerce and its corrupting, inegalitarian effects than that provided by Rousseau (Nakhimovsky 2011). Nakhimovsky presents Fichte as trying to carve a space out between Rousseau's pessimistic insistence on the impossibility of reconciling commerce with individual freedom and so on a politics of peasant virtue, and Kant's more optimistic reading of the civilizing interdependence that international trade would create once the fiscal-military state had collapsed beneath the burden of the debt it required to fed itself, as it inevitably would. While Fichte rejected the halting of the development of human potential that Rousseau's vision would impose (Nakhimovsky 2011, 151ff), he also saw Kant's claim that belligerence and militarised competition were in the long term unsustainable as overly optimistic, at least without condemning indefinitely many more generations to continual conflict rather than perpetual peace (Nakhimovsky 2011, 66ff). On Nakhimovsky's account, Fichte presents himself with a problem not unlike that facing contemporary internationalizing egalitarians. Rousseau's solution to the problem of international trade's penetration into the domestic economy requires an authoritarian confining of the human spirit beyond the price anyone interested in individual liberty should be willing to pay. Nor though can we sit back and blithely wait for sweet commerce to unite us all in a world of reciprocal cooperation, promising that the destructive competition it currently unleashes is but a prelude to sunlight uplands dimly visible on the horizon.

Fichte's solution to the problem he shares with contemporary internationalizing egalitarians should, however, give them pause. The closed commercial state would have reconciled 
prosperity with equality by abruptly cutting off all commercial contact with foreigners through the sudden introduction of a fiat currency with no exchange rate and using the autarkic opportunity it presents to create a centrally planned economy which ensures both work for all at roughly equal rates of pay and a large and growing basket of goods on which to spend that pay. International contact would then be restricted to scientific exchanges and bilateral barter for any surplus the planned economy generated so that, for example, northern Europeans could swap their some of their grain for southern European wine (Nakhimovsky 2011, 84). Only by ending any role for international trade in the domestic economy could the competition it engendered be controlled, Fichte claimed. The incomplete transition from a single European market, created under the Roman Empire and persisting through the feudal era, to a Europe of independent states had to be finished by breaking up the continent-wide and increasingly global economic order. The nascent states that were politically and militarily separating and competing over that order's members were nonetheless parasitic on it, seeking to extract as much benefit as they could from it. They would continue to do so until they were prevented by aligning their sources of economic success with the territory and population over which they properly ruled through a radical break with the prevailing economic order.

Fichte's plan for the creation of a new currency to break cycles of beggar thy neighbour economic competition drew on a tradition of such plans going back to John Law and his eventually disastrous attempt to recapitalise the French economy by converting its public debt into shares, more of which could be issued (Nakhimovsky 2011, 119ff). Whatever the real economic possibilities and costs of ending jealousy of trade by ending international trade altogether ever were, and of course there is ample evidence that they are respectively negligible and extremely high, even much more moderate uses of fiat currencies had already been subject to extensive political criticism. Allowing the state full control over the economy through money not tied to anything of real and stable exchange value would put it in a position to expropriate its opponents at will, a power with which it could not be trusted and which was bound to lead to despotism. Given the role of central banks in contemporary political economy, we have presumably overcome that worry about state-backed currencies, if not all others about money as a political tool (Streeck 2017). Fichte's plan for us presumably runs into a different political constraint, that of our scepticism about centralized economic planning on the scale he suggests, both as a mechanism for effective producing the goods and services needed to meet consumer demand and as a form of rule which seems to inevitably require institutionalized brutality and corruption (Sagar 2018, 15ff). Planning on the scale he envisaged is simply not an option for contemporary internationalizing egalitarians. 
Nakhimovsky points out that something like Fichte's closed commercial state seems to have been in the mind of various egalitarian-inclined figures in the twentieth century, perhaps most notably Keynes who in his National Self-Sufficiency in 1933 suggested radically reducing international trade (Nakhimovsky 2011, 171ff). However, Keynes, presumably with some obvious exemplars in mind, was there at pains to emphasize that any such reorientation could only be attempted gradually if unacceptable levels and forms of state violence were not to be required. That incrementalism would presumably have disappointed Fichte, who after all had criticized Kant's account precisely for postponing deliverance from international political and economic anarchy until after some unlikely millennium. The radicalism of Fichte's view is in part a response to the radicalism of his diagnosis of the problems it is meant to solve. Contemporary internationalising egalitarians face a similar problem. The international economic order does not seem to be increasing in stability while the vehicles and forces of domestic egalitarianism seem increasingly fractured and disenfranchised. Even if a gradual reorientation away from international trade were to be an in principle sustainable strategy, which of course it may not be, waiting in the expectation that political egalitarians will be in a position to benefit from its eventual success by capturing the now fully empowered state apparatus seems a triumph of hope over experience. The problem of finding a stable and acceptable domestic politics which can coexist with or initiate the reform of a dangerously unruly international order remains.

\section{Conclusion}

The central point of asking about the stability of the egalitarian relations internationalising egalitarians hope to achieve is not to advocate either Rousseau's or Fichte's conceptions of or solutions to the problems created by the international economy's penetration of domestic societies. It is instead to problematize the absence of thinking about the relations between the international economic order and its institutions and domestic societies dynamically. Internationalising egalitarians are not proposing trying to stop the world so that they can get off. They do not usually see the liberalization of societies that has often accompanied their increasing penetration by international economic forces as a loss, in the way that for example Streeck's discussion of women's entrance into the labour market sometimes suggests he does (Streeck 2017, 217ff). They are often rather powerfully aware of the costs of tightly knit groups and communities (Ronzoni 2011), and so clearly not enthusiastic about recreating them. Nor do their discussions suggest that they hope to end, rather than control, international commercial transactions. 
In one sense though, that internationalising egalitarians do not want to stop the world highlights the problem they have, of how it may change, particularly as a result of the institutions they propose. The issue is how to understand the interactions between the domestic, transnational and supranational institutions they advocate, and whether the motives those different institutions will require of their members to function are compatible, attractive and minimally realistic. It is very unlikely that, given the various agents, institutions and interactions amongst them the world contains, all or even most of our political hopes can become sensible commitments, even at a comparatively abstract theoretical level. As Christopher Brooke has pointed out in his provocative juxtaposition of Montesquieu's advocacy of honour as the organizing principle of a modern monarchy and Aaron James' work on assholes, unpleasant personal characteristics may be necessary corollaries of otherwise desirable or even required political arrangements. Perhaps an unjustified sense of one's own importance as a member of privileged caste or class is the only way to motivate necessary resistance to political power and authority that inevitably carries the risk of becoming overweening, oppressive or despotic (Brooke 2018). There seem to be good reasons to think that internationalizing support for state attempts to achieve domestic equality will generate tensions, both because putting political power beyond the reach of those over whom it rules is inegalitarian and because of the various effects of doing so, not least of which is the creation of various resentments easily captured and redirected by illiberal reactionaries. Even if internationalising support for equality can avoid the related dangers of an elite technocracy that protects its own and a nativist backlash against distant international institutions, the way it evacuates the domestic public sphere is itself undesirable and dangerous. If political action is to be increasingly transnational, then domestic political parties, particularly those of the left, will increasingly struggle to build united coalitions of the domestic beneficiaries of equality, who may be set against each other or simply drawn into other political orientations, affinities and commitments by the multiplication of arenas in which to press their claims.

Concerns about the stability of internationalising domestic equality may well be resolvable. That it is unlikely that we can achieve all our understandable hopes does not mean that we cannot. That remains to be shown though, even if at least some internationalising egalitarians realize that our present predicament requires moving beyond something like one last push towards domestic social democracy (Ronzoni 2018) - as indeed the logic of their position, at least relative to the rest of contemporary analytical political theory and philosophy, suggests. Confronting the tensions I hope I have demonstrated in this piece then is a central requirement of a realistic internationalising egalitarianism. Nor are those tensions new ones. They are in fact structurally very similar to those which served as an organizing problematic for a significant part of the republican tradition which, even when contemporary egalitarians do not present 
themselves as operating within, serves as a resource on which they draw. Turning back to the eighteenth century and jealousy of trade most thoroughly worked through by István Hont can help frame many problems in contemporary political theory. Analytical political theorists concerned with domestic socio-economic and political equality have recently become increasingly concerned about the inegalitarian effects of commerce, and are looking to international political institutions to control them. Yet these internationalising egalitarians' eighteenth century predecessors failed to find a way of taming those inegalitarian effects which did not raise the prospect of costs we at least now see as unacceptable. Whether Hont was right that we are now living in the future imagined by eighteenth century theorists of commercial society and whether that is sustainably compatible with the kinds of international control of commerce internationalising egalitarians demand are consequently vital questions for their project to answer. 
Notes

i Inequality between states and in particular across the world has fallen since the end of the Cold War, mainly because of the rise of China. Nearly a billion people have been lifted out of poverty in East Asia and the Pacific since 1990 (World Bank 2017, 25), the significant majority of them in China. Analytical political theorists and philosophers have though, for better or worse, been more interested in changes in the societies in which they mostly live.

ii Hont's posthumously published Carlyle Lectures (2015) attack this reading of Rousseau as opposed to commerce and luxury. There is reason though both to be suspicious of the account of Rousseau presented there and of whether Hont had completed his work on the text, which was assembled from notes. As Robin Douglass has shown, Hont's argument that Rousseau was a theorist of commercial society depends on equivocating between that concept as way of picking out a particular kind of social formation and a broader theory of human sociability, as well as on highlighting some parts of Rousseau's corpus over others (Douglass 2018). Hont's revisionary reading of Rousseau is also markedly less egalitarian. Even if we were to accept Hont's revisionary reading then, this would not necessarily alleviate the tension between contemporary egalitarians' commitment to socio-economic equality and the politics of peasant virtue often associated with Rousseau.

iii Hont's revisionary reading of Rousseau in his posthumously published Carlyle Lectures (2015) does not dispute that the choice is between equality and an illiberal politics of virtue or liberty and greater scope for self-seeking and the corruption and dishonesty that comes with it. His claim instead is that Rousseau accepts commercial society and so rejects the equality and virtue pair.

Acknowledgments

I presented this paper at the American Political Science Association and the University of Reading, and I would like to thank both of those audiences for their useful comments. I also received written comments from Margherita de Candia, Aart van Gils, Miriam Ronzoni and Paul Sagar as well as two anonymous reviewers, all of which were very helpful.

Disclosure Statement

No conflicts of interest were reported by the author

Note on contributor

Robert Jubb is an Associate Professor of Political Theory at the University of Reading. His work focuses on methodological questions in political theory and philosophy, particularly in the contexts of the value of equality and of structural injustice, and is currently working on a project on protest and resistance. His work has appeared in European Journal of Political Theory, Journal of Ethics and Social Philosophy, Journal of Moral Philosophy, Journal of Politics, Political Studies and Social Theory and Practice.

References

Anderson, Elizabeth. 1999. "What is the Point of Equality?" Ethics 109 (2): 287-337.

Beitz, Charles R. 1975. "Justice and International Relations." Philosophy and Public Affairs 4 (4): 360-389.

Bell, Duncan. 2014. “What is Liberalism?” Political Theory 42 (6): 682-715.

Bellamy, Richard. 2019. A Republican Europe of States: Cosmopolitanism, Intergovernmentalism and Democracy in the EU. Cambridge: Cambridge University Press.

Bourget, David, and David J Chalmers. 2014. "What Do Philosophers Believe." Philosophical Studies 170 (3): 465-500. 
Brooke, Christopher. 2018. "Arsehole Aristocracy (Or, Montesquieu on Honour Revisited)." European Journal of Political Theory 17 (4): 391-410.

Douglass, Robin. 2018. “Theorising Commercial Society: Rousseau, Smith and Hont.” European Journal of Political Theory 17 (4): 501-511.

Hont, Istvan. 2015. Politics in Commercial Society. Edited by Bela Kapossy and Michael Sonenscher. Cambridge: Harvard University Press.

—. 2005. The Jealousy of Trade. Harvard: Harvard University Press.

Hont, Istvan, and Michael Ignatieff, . 1983. Wealth and Virtue: The Shaping of Political Economy in the Scottish Enlightenment. Cambridge: Cambridge University Press.

James, Aaron. 2013. Fairness in Practice: A Social Contract for a Global Economy. Oxford: Oxford University Press.

Jubb, Robert. 2015. “The Real Value of Equality.” Journal of Politics 77 (3): 679-691.

Laborde, Cecile, and Miriam Ronzoni. 2016. "What is a Free State? Republican Internationalism and Globalisation." Political Studies 64 (2): 279-296.

Mair, Peter. 2013. Ruling the Void. London: Verso.

Nagel, Thomas. 2005. “The Problem of Global Justice.” Philosophy and Public Affairs 33 (2): 113147.

Nakhimovsky, Isaac. 2011. The Closed Commercial State. Princeton: Princeton University Press. Neuhouser, Frederick. 2013. "Rousseau's Critique of Economic Inequality.” Philosophy and Public Affairs 41 (3): 193-225.

O'Neill, Martin. 2008. "What Should Egalitarians Believe." Philosophy and Public Affairs 36 (2): 119-156.

O'Neill, Martin, and Thad Williamson, . 2012. Property-Owning Democracy: Rawls and Beyond. Oxford: Wiley-Blackwell.

Pettit, Philip. 2012. On the People's Terms. Cambridge: Cambridge University Press.

—. 1997. Republicanism: A Theory of Freedom and Government. Oxford: Oxford University Press.

Pocock, J. G. A. 1975. The Machiavellian Moment: Florentine Political Thought and the Atlantic Republican Tradition. Princeton: Princeton University Press.

Rawls, John. 1971. A Theory of Justice. Cambridge: Harvard University Press. 
Ronzoni, Miriam. 2018. "How Social Democrats May Become Reluctant Radicals: Thomas Piketty's Capital and Wolfgang Streeck's Buying Time." European Journal of Political Theory 17 (1): 118-127.

Ronzoni, Miriam. 2018. "Justice, Injustice and Critical Potential Beyond Borders: A Multidimensional Affair." Journal of Applied Philosophy 35 (1): 90-111.

Ronzoni, Miriam. 2011. "Life Is Not a Camping Trip: On the Desirability of Cohenite Socialism." Politics, Philosophy and Economics 11 (2): 171-185.

Ronzoni, Miriam. 2017. "Republicanism and Global Institutions: Three Desiderata in Tension.” Social Philosophy and Policy 34 (1): 186-208.

Ronzoni, Miriam. 2017. “The European Union as a Demoicracy: Really a Third Way?” European Journal of Political Theory 16 (2): 210-234.

Ronzoni, Miriam. 2009. "The Global Order: A Case of Background Injustice? A PracticeDependent Account." Philosophy and Public Affairs 37 (3): 229-256.

Rousseau, Jean-Jacques. 1997. "Discourse on the Origins and Foundations of Inequality among Men." In The Discourses and Other Early Political Writings, by Jean-Jacques Rousseau, edited by Victor Gourevitch, 111-188. Cambridge: Cambridge University Press.

Rousseau, Jean-Jacques. 1997. "Of the Social Contract." In The Social Contract and Other Later Political Writings, by Jean-Jacques Rousseau, edited by Victor Gourevitch, 39-152. Cambridge: Cambridge University Press.

Sagar, Paul. 2018. "Istvan Hont and Political Theory." European Journal of Political Theory 17 (4): 476-500. doi:10.1177/1474885118782385.

Skinner, Quentin. 1997. Liberty before Liberalism. Cambridge: Cambridge University Press. Skinner, Quentin. 2010. “On Slogans of Republican Political Theory.” European Journal of Political Theory 9 (1): 95-102.

Smith, Adam. 1975. An Inquiry into the Nature and Cause of the Wealth of Nations. Oxford: Oxford University Press.

Streeck, Wolfgang. 2014. Buying Time: The Delayed Crisis of Democratic Capitalism. Translated by Patrick Camiller and David Fernbach. London: Verso.

Streeck, Wolfgang. 2017. "How to Study Contemporary Capitalism." In How Will Capitalism End?, by Wolfgang Streeck, 201-225. London: Verso.

Streeck, Wolfgang. 2017. "Why the Euro Divides Europe.” In How Will Capitalism End?, by Wolfgang Streeck, translated by Rodney Livingstone, 165-183. London: Verso. 
Williams, Bernard. 1997. "Forward to Basics." In Equality, by jane Franklin, 49-58. London: IPPR.

Wolkenstein, Fabio. 2018. “Demoicracy, Transnational Partisanship and the EU.” Journal of Common Market Studies 56 (2): 284-299.

World Bank. 2017. World Bank Development Indicators 2017. Washington, DC: World Bank. Young, Iris Marion. 2011. Responsibility for Justice . Oxford: Oxford University Press. 